\title{
FACTORS AFFECTING COMPANY'S CAPABILITY IN PERFORMING INTEGRATED REPORTING: AN EMPIRICAL EVIDENCE FROM INDONESIAN
}

\author{
Putu Sukma Kurniawan ${ }^{1}$ \\ Department of Accounting \\ Universitas Pendidikan Ganesha \\ putusukma@undiksha.ac.id
}

\author{
Made Arie Wahyuni \\ Department of Accounting \\ Universitas Pendidikan Ganesha \\ ariewahyuni@undiksha.ac.id
}

\begin{abstract}
ABSTRAK
Penelitian ini menguji faktor yang mempengaruhi kemampuan perusahaan untuk melakukan pelaporan terintegrasi. Analisis yang dipergunakan dalam pengujian hipotesis adalah analisis regresi linier berganda. Hasil penelitian menunjukkan bahwa ukuran perusahaan berpengaruh positif dan signifikan dan tekanan pemangku kepentingan berpengaruh negatif dan signifikan terhadap kemampuan perusahaan melakukan pelaporan terintegrasi. Hasil penelitian juga menunjukkan bahwa profitabilitas perusahaan, kepemilikan manajerial, dan kepemilikan institusional tidak memiliki pengaruh terhadap kemampuan perusahaan melakukan pelaporan terintegrasi..
\end{abstract}

Kata Kunci : pelaporan terintegrasi; profitabilitas perusahaan; ukuran perusahaan; kepemilikan manajerial; kepemilikan institusional;

\begin{abstract}
This study examines the factors that affect the company's capability to perform integrated reporting. The analysis used in testing the hypothesis is multiple linear regression analysis. Results show that company's size has positive and significant connection and stakeholder's pressure has negative and significant connection with the company's capability in performing integrated reporting. In contrast, level of company's profitability, company's managerial ownership, and company's institutional ownership did not have enough connection with company's capability in performing integrated reporting.
\end{abstract}

Keywords : $\quad$ integrated reporting; company's profitability; company size; managerial ownership; institutional ownership;

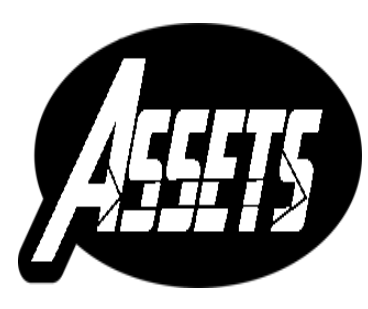

ASSETS

Jurnal Akuntansi dan Pendidikan

Vol. 7 No. 2

Hlmn. 141-155

Madiun, Oktober 2018 p-ISSN: 2302-6251

e-ISSN: 2477-4995

Artikel masuk: 16 Oktober 2018 Tanggal diterima: 31 Oktober 2018 


\section{INTRODUCTION}

The concept of the company's business has significant changes in recent decades. At first, the company's business aims only to prosper the management and shareholders of the company and also focuses on stakeholder's interest. The company focuses only seek maximum profits to their shareholders by using all available resources. This perspective will make the company an "individual organization" who only thinks of their own interests. This paradigm began to be abandoned by another paradigm.

The new paradigm or concept proposes that companies should provided benefits to all stakeholders of the company. Within this context, stakeholders of the company are not only internal stakeholders but also the company's stakeholders that are outside the company. Outside stakeholders should be considered by the company's management as an important stakeholders and this stakeholder group can give legitimacy to the business activities undertaken by the company. Company's management should realize about stakeholder's interest and the best way to help each stakeholder groups in decision-making process context is delivering the comprehensive information about company's circumstances.

This concept will change the paradigm of corporate reporting. At first, the company's management solely focused on the financial information related to the company. Financial information is delivered through financial reporting and at that time the company's performance only seen from the economic value generated by the company. The impact of this financial reporting is the company's stakeholders only examine the company based on the rate of profit, the value of the debt, and other accounting numbers while the performance of companies in terms of risk management, human resource empowerment, and awareness of the sustainability concept cannot be assessed.

Flower (2015) argues that the business is currently experiencing challenges in the context of the information disclosure to company's stakeholders. Financial reporting model that focuses absolutely on financial values is not sufficient for the company's stakeholders to assess the current performance of the company's and also past and future performance (Flower, 2015). The report from KPMG (2011) showed that management in the big company has a new perspective to disclose their non-financial information, particularly information about sustainability concept and corporate governance.

The development of business system requires the company's management create a sustainability report. A sustainability report is a form of corporate responsibility to company's stakeholders (Amran \& Keat Ooi, 2014). Sustainability report contains about aspects undertaken by the company in the economic, social, and environmental context. Some companies in Indonesia, which have been listed on the Indonesia Stock Exchange, disclose their social and environmental activities that have been performed and present that information in a corporate sustainability report. The basis of the content of the sustainability report is that the business model developed by the company must be based on the concept of the triple bottom lines, namely profit, people, and planet. In general, the company should balance its performance in the economic field with the performance on the social and environmental fields. Dumay et al. (2016) stated that the trend to disclose social and environmental information increased significantly and this process improve the quality and accountability of information from the company's management to their stakeholders.

In 2011, a reporting concept that combines the financial information reporting and non-financial information reporting was raised. This reporting model was 
recommended by the IIRC (The International Integrated Reporting Council's) in collaboration with the Global Reporting Initiatives (GRI). The reporting model called integrated reporting (IR). Integrated reporting is expected to be one of the factors that can determine the value of the company which will be measured by the financial information and non-financial information produced by the company's management. Integrated reporting is a perfect way to communicate with the company's stakeholder based on the company's efforts to create sustainability in their business activities.

In 2013, IIRC (The International Integrated Reporting Council's) released a conceptual framework for integrated reporting. The conceptual framework of the integrated reporting contains the company's ability to sustain economic performance, corporate strategies in improving human resources, and the company's role in supporting the environment. One of the goals of integrated reporting is to improve the quality of information for the company's stakeholders. In this context, the quality of the information would be more qualified and this is important in stakeholder decisionmaking process. The conceptual framework of integrated reporting is created to improve the quality of information for stakeholders (particularly in capital markets) to achieve efficiency and build appropriate decisions in the allocation of capital.

Setia et al. (2015) showed that integrated reporting is done in South Africa has increased the disclosure of information regarding employment, social, natural or environmental, and intellectual capital in companies listed on the Johannesburg Stock Exchange (JSE). Stakeholders can assess or examine the company's performance more comprehensive and full information about the company's condition can be incorporated into an integrated report. Villiers et al. (2014) found that to meet the interests of the company's stakeholders, financial information and non-financial information should be integrated into a single report. Abeysekera (2013) argues that there is a contemporary paradigm in business context, from investors who focus only on financial information into investors who focus on sustainable responsible investment and the company's sustainability performance.

Based on the description, this study focuses on the determinants of the integrated reporting process and this topic is important in the context of capital market (financial market). Setia et al. (2015) explained that integrated reporting is a key to create efficiency in the capital market. Setia et al. (2015) found integrated reporting as a connector between the company's management performances and the level of expectation from company's stakeholders. Based on this opinion, it is very interesting to examine the factors that affect the capability of Indonesian companies to conduct integrated reporting process.

Generally, the independent variables in this study are derived from the company's internal characteristics with the dependent variable is the company's capability in performing integrated reporting. This research is based on previous studies that examined the context of integrated reporting. Stubbs and Higgins (2014) examined the practice of integrated reporting in Australia and found that highly integrated reporting process requires a change in corporate culture. Solomon \& Maroun (2012) shows that there has been no strong evidence that the corporate behavior will increase the quality of integrated reporting process. Steyn (2014) found that the board of directors strongly supports a policy on integrated reporting and believes that the benefits of integrated reporting process will exceed the cost in preparing the integrated report in South Africa.

Independent variables in this study, managerial ownership and institutional ownership, is based on Frias-Aceituno et al. (2013) which states that corporate governance mechanisms, such as the board of directors, have an important role in the 
implementation of corporate social responsibility and improving the quality and transparency of information to company's stakeholders. Beurden and Gössling (2008) found that the institutional agencies will tend to invest in companies with a high reputation and a good action in social performance. Rouf (2011) and Bidaki and Hejazi (2014) proved that profitability had a positive relationship with company's information disclosure level. Previous research stated that the company's profitability level has a significant impact to the level of corporate reports.

Galani et al. (2011) found a company with a large size may have sufficient resources to reduce the information production cost in the company's annual report, and then this process will increase the disclosure level. Frias-Aceituno et al. (2013) explained that the company's size is one of the important factors in the dissemination of integrated reporting. The element of corporate governance is one of the main infrastructures that support the development of integrated reporting in business systems. Frias-Aceituno et al. (2013) argued that the board of directors can play an important role in the process of social and environmental disclosure. Results from Frias-Aceituno et al. (2013) explained that the board is one important factor in the process of integrating the disclosure of financial information and non-financial information. The preparation of the hypothesis in this study is also based on research conducted by Steyn (2014) who found that the directors of the company in South Africa recognized the benefits of the integrated reporting process and believes that the value of these benefits will exceed the costs to prepare an integrated report. Research Van Beurden and Gössling (2008) explained that the board's commitment is one important factor in integrating the disclosure of financial information and non-financial information.

The company with the high reputation and good social performance is considered to have a strong legitimacy in doing business. This fact indicates that institutional investors have high expectation with company's social and environmental activities. Huang (2010) argue that institutional investors want "social standard criteria" when selecting companies for investment. Ali and Rizwan (2013) said that institutional investors have a great influence on corporate social disclosure, particularly for companies operating in developing countries. Result from Ali and Rizwan (2013) supports the research of David and Kochhar (1996) which created a conclusion that there is a positive and significant relationship between institutional investor ownership in companies with company's social and environmental disclosure. Abeysekera (2013) explained that there has been a change in the viewpoint of investors in the capital market and this day investors are very focused on sustainable responsible investment (SRI). Stakeholder's pressure variable can be explained by the legitimacy theory and stakeholder theory. Stakeholder's pressures are the "pressure" from company's stakeholders to the company's management to disclose financial information and non-financial information (comprehensive information). Galani et al. (2011) explained that the company's with large size should disclose their business activities to public and this information is important to build public knowledge. This process will create an information request from the company's stakeholder to the company's management. The strong stakeholder's pressure will encourage the company's management to disclose financial information and non-financial information. Companies with relatively large stakeholder groups will strive to disclose comprehensive information, including disclosing non-financial information. Zadeh and Eskandari (2012) revealed that when information is requested from the company's stakeholder to the company's management, the impact of this process is the 
information asymmetry problem. The concept of integrated reporting can be used to reduce the impact of information asymmetry.

The main theory of the conceptual framework in this research is based on stakeholder theory and the legitimacy theory. The stakeholder theory explains that the existence of the company not only to maximize the interests of shareholders but also to serve the interests of other stakeholders associated with the company. The stakeholder theory in the research framework is represented by the stakeholder's pressure variable. The legitimacy theory explains that company's social and environmental disclosure is important to gain legitimacy for the company's operations from all stakeholders. The conceptual framework is prepared by the argument that the company conducts integrated reporting will be influenced by two factors or two variables. These factors are factors that generate from internal and external. In this study, internal factors are represented by the variable of company's profitability, company's size, managerial ownership level, and institutional ownership level. The external factor of the company is represented by the stakeholder's pressure variable.

Jo and Harjoto (2011), in their research on corporate governance and corporate value, stated a hypothesis called the conflict-resolution hypothesis. The hypothesis explains that if managers use monitoring mechanisms and effective corporate governance in relation to social and environmental activities of the company to resolve conflicts among stakeholders, then the value of the company will be positive. Companies with a high level of management ownership will have a better ability to disclose financial information and non-financial information in this context and this condition is used to reduce conflict with the company's stakeholders. The hypothesis from Jo and Harjoto (2011) is also supported by a statement from Utama (2011) which stated that mechanism and structure of corporate governance is one of the important infrastructures to support corporate social and environmental reporting.

Sawarjuwono (2012) argues that company's management should have a new paradigm in managing the company, and then this paradigm will create the company's social responsibility as a part of the corporate culture. This paradigm explains that company's management should create a harmony with the social and environmental fields. The company's management must argue that the social community and the natural environment is a part of the company's ecosystem. The effort from company's management to release integrated report is a perfect start to improve the quality of information and this process can help company's stakeholders create a good decisionmaking process.

Based on the research introduction, this study suggests five hypotheses, namely

H1: The company's profitability has a positive effect and significant to the company's capability in performing integrated reporting.

H2: The company's size has a positive effect and significant to the company's capability in performing integrated reporting.

H3: The managerial ownership level has a positive effect and significant to the company's capability in performing integrated reporting.

H4: The institutional ownership level has a positive effect and significant to the company's capability in performing integrated reporting.

H5: The stakeholder's pressure has a positive effect and significant to the company's capability in performing integrated reporting. 


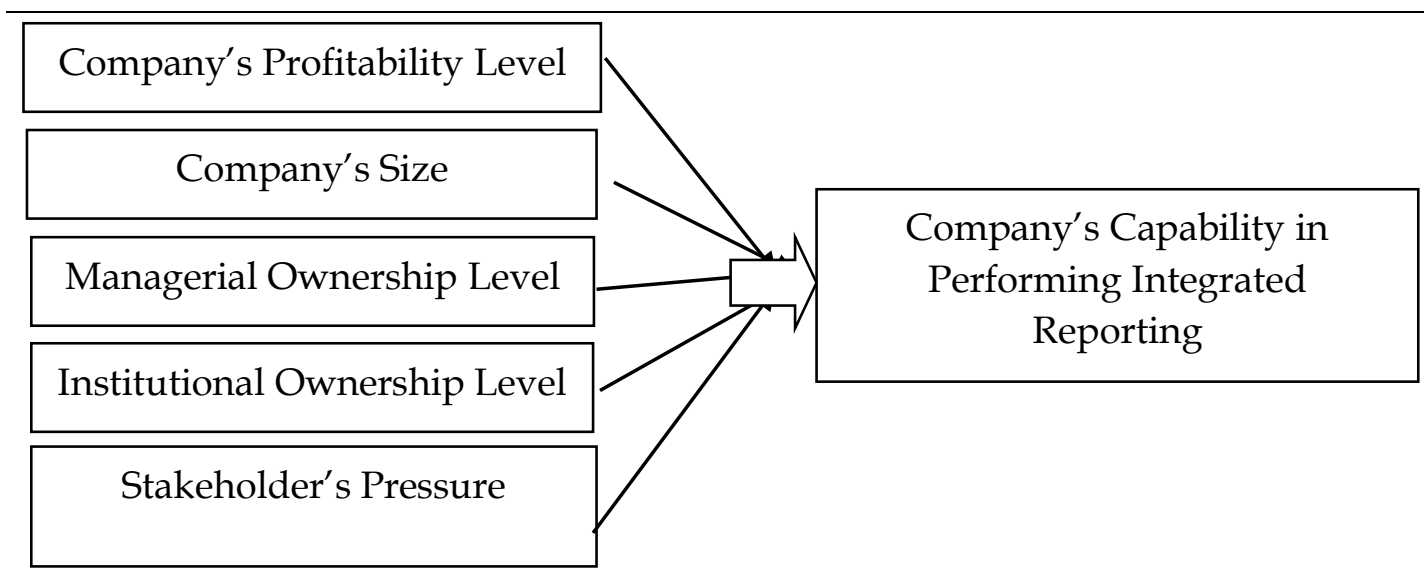

Figure 1. Research Framework

\section{RESEARCH METHODS}

The study is based on the quantitative or positivist paradigm. The author assumes that each of the variables in this study has a causal relationship. The design of this study aims to find the effect of independent variables on the dependent variable. The independent variables in this study are the company's profitability, the company's size, managerial ownership level, institutional ownership level, and stakeholder's pressure and the dependent variable is the company's capability in performing integrated reporting.

The populations in this study are companies that competed for Indonesia Sustainability Reporting Award (ISRA) which organized by the National Center for Sustainability Reporting (NCSR) and companies listed on the SRI-KEHATI stock index. A period of observation in this study was conducted over three years, from 2014 to 2016. This study used the population of companies that follow ISRA and listed companies in the SRI-KEHATI stock index due to the assumption that companies that follow the ISRA and listed companies in SRI-KEHATI stock index can be categorized as companies that have implemented the sustainability concept in their business activities. Companies that have implemented the concept of sustainability will tend to have a high ability to perform integrated reporting.

Purposive sampling was used as a technique of sampling. The specific criteria of the samples are (1) participate in the ISRA competition (minimal 1 year participate in the ISRA competition) and listed on SRI-KEHATI stock index (minimal 2 periods listed on SRI-KEHATI stock index), (2) publishing or releasing a sustainability report, (3) using the GRI Standard in preparing a sustainability report or using the Integrated Reporting Framework in preparing integrated report (if the company's management has released an integrated report), (4) use the Rupiah in the financial statements, (5) company's financial statements and company's sustainability report can be accessed in the official website of Indonesia Stock Exchange and in the company's official website, and (6) the company's management provides financial report and sustainability report during the period 2014-2016. Based on purposive sampling methods, then the samples are 40 companies. Observation time span is 3 years and total observations are 120 observations.

The data in this research is secondary data, namely the company's financial statements and the corporate sustainability reports. To conduct an analysis of the variables of company's profitability, company's size, managerial ownership level, institutional ownership level, and stakeholder's pressure then the data source is the company's financial statements. For company's capability in performing integrated reporting variable, the data source is the corporate sustainability report or using the 
integrated report for a company that has developed an integrated report. Data regarding the company's financial statement and corporate sustainability report obtained through the official website of Indonesia Stock Exchange or the company's official website.

Table 1. Research Samples

\begin{tabular}{clc}
\hline No & \multicolumn{1}{c}{ Sample Source } & Number of Companies \\
\hline 1 & ISRA Competition & 16 \\
2 & SRI-KEHATI Stock Index & 24 \\
3 & Total sample & 40 \\
\hline
\end{tabular}

This study chooses the ratio of Return on Assets (ROA) to measure the level of profitability which compares the company's net income with the total assets owned by the company. ROA has been selected because this ratio can be used to measure the company's profitability and see the management efficiency in using corporate assets or resources to generate a net operating profit. ROA ratio is calculated by dividing net income at the end of the year with the total assets. Company's size in this study was measured using the logarithm of the company's total assets or ln total assets. Managerial ownership is a shareholder from management group who has a voice to participate in decision-making within the company's activities. In this study, managerial ownership was measured by the percentage of shares ownership held by the board of directors and board of commissioners divided by the total number of shares outstanding. Institutional ownership is the percentage of shares ownership owned by another institution. In this research, institutional ownership is measured by the percentage of the shares value owned by an institution (institutional investor) divided by the total number of shares outstanding. The stakeholder's pressure variable in this study is defined as the pressure from the government and pressure from the majority shareholders. Measurement of stakeholder's pressure variable is based on the total shares owned by the government with the total stock of the majority shareholder.

The company's capability to perform integrated reporting is measured using the International Integrated Reporting Framework (The International <IR> Framework) prepared by the International Integrated Reporting Council (IRRC) and the Guidance on the Strategic Report issued by the Financial Reporting Council (FRC). The company's capability to perform integrated reporting is measured by total disclosure items that have been disclosed in the company's sustainability report and in accordance with The International <IR $>$ Framework and Guidance on the Strategic Report. The International $<\mathrm{IR}>$ Framework requires that company's integrated report must include eight elements of information: (1) organizational overview and operating context, (2) governance, (3) business model, (4) risk and opportunities, (5) strategy and resource allocation, (6) performance, (7) outlook, and (8) basis of preparation and presentation. While in the Guidance on the Strategic Report, the information that must be disclosed by the company's management consists of three categories: (1) strategic management, (2) business environment, and (3) business performance. Category of strategic management consists of strategy and objectives and also business model, business environment category consists of the trends and factors, principal risks and uncertainties, environmental, employee, social, community, and human rights matters, and the category of business performance consists of the analysis of performance and position, key performance indicators (KPIs), and employee gender diversity.

The regression analysis model which used in this study is a multiple linear regression analysis model. The multiple linear regression analysis model in this research, namely 


$$
\mathrm{KPT}=\alpha+\beta_{1} \mathrm{PROFIT}+\beta_{2} \mathrm{SIZE}+\beta_{3} \mathrm{MANAGE}+\beta_{4} \mathrm{INS}+\beta_{5} \mathrm{PRESS}+\mathrm{e}
$$

$\begin{array}{ll}\text { KPT }(Y) & =\text { The company's capability in performing integrated reporting } \\ \alpha & =\text { The constanta } \\ \beta_{1}, \beta_{2}, \beta_{3}, \beta_{4}, \beta_{5} & =\text { The regression coefficients } \\ \text { PROFIT }\left(X_{1}\right) & =\text { The company's profitability } \\ \text { SIZE }\left(X_{2}\right) & =\text { The company's size } \\ \text { MANAGE }\left(X_{3}\right) & =\text { The managerial ownership level } \\ \text { INS }\left(X_{4}\right) & =\text { The institutional ownership level } \\ \text { PRESS }\left(X_{5}\right) & =\text { The stakeholder's pressure } \\ \text { e } & =\text { The residual error }\end{array}$

\section{RESULTS AND DISCUSSION}

Based on the test results of descriptive statistics, it can be seen that the minimum value for the managerial ownership level is 0 . It means that there are companies in the research sample did not have managerial ownership. The mean of the data showed that the majority of companies in the sample had an institutional ownership level $(0,7084)$, greater than the level of managerial ownership $(0,0272)$. It means that the majority of companies in the sample are owned by institutional investors. The minimum profitability and the maximum profitability occur in companies in the manufacturing industry. The largest company size was also owned by companies from the manufacturing industry. The logical explanation why maximum profitability occur in manufacturing companies is based on the connection between company's size and company's profitability. The "big company" will have enough resource (capital, human resource, and investment) to generate high profitability level. The largest managerial ownership $(0,244)$ was owned by companies from the manufacturing industry, while the largest institutional ownership $(0,9818)$ was in the banking industry. The level of institutional ownership in banking industry is supported by institutional investors from foreign country.

Table 2. Descriptive Statistics Test Result

\begin{tabular}{|c|c|c|c|c|c|}
\hline No & Variables & $\mathbf{N}$ & Minimum & Maximum & Mean \\
\hline 1 & PROFIT & 120 & 0,00095 & 0,4156 & 0,1304 \\
\hline 2 & SIZE & 120 & 25,22 & 32,837 & 28,3 \\
\hline 3 & MANAGE & 120 & 0 & 0,244 & 0,0272 \\
\hline 4 & INS & 120 & 0,3711 & 0,9818 & 0,7084 \\
\hline 5 & PRESS & 120 & 0 & 0,6 & 0,2452 \\
\hline 6 & KPT & 120 & 0,264 & 0,6742 & 0,4113 \\
\hline
\end{tabular}

The test result showed that the Adjusted $\mathrm{R}^{2}$ value is equal to 0,427. It means that $42,7 \%$ of the variation of the company's capability to perform integrated reporting variable can be explained by all the independent variables. Future studies should consider using other independent variables to increase the value of Adjusted $\mathrm{R}^{2}$.

Table 3. Adjusted R Square Test Result

\begin{tabular}{cc}
\hline Model & Adjusted R Square \\
\hline 1 & 0,427 \\
\hline
\end{tabular}


Table 4. Individual Parameter Significance Test Result

\begin{tabular}{clcc}
\hline No & Variables & Unstandardized Coefficients & Sig. \\
\hline 1 & PROFIT & 0,038 & 0,680 \\
2 & SIZE & 0,037 & 0,000 \\
3 & MANAGE & $-0,199$ & 0,216 \\
4 & INS & $-0,073$ & 0,252 \\
5 & PRESS & $-0,258$ & 0,001 \\
\hline
\end{tabular}

From the four independent variables included in the regression model, it can be explained that the PROFIT variable (company's profitability), MANAGE variable (the level of managerial ownership), and INS variable (the level of institutional ownership) have a significance value respectively 0,680,0,216, and 0,252 (greater than a =0,05). Based on the significant value, it can be concluded that the company's profitability, managerial ownership level, and the level of institutional ownership is insignificant or no effect on the company's capability in performing integrated reporting. In other words, the hypothesis 1, hypothesis 3 and hypothesis 4 were rejected.

The SIZE variable (company's size) and PRESS variable (stakeholder's pressure) have a significance value of 0,000 and 0,001 (smaller than $a=0,05$ ). Based on these data, it can be concluded that the company's size and stakeholder's pressure have significant influence to the company's capability in performing integrated reporting. The unstandardized coefficients value of SIZE variable (company's size) is 0,037 which mean that the company's size has a positive connection with the company's capability in performing integrated reporting. It means that if the company's size is larger, the company's ability to perform integrated reporting will increase. The unstandardized coefficients value of the PRESS variable (stakeholder's pressure) is $-0,258$. It can be defined that the stakeholder's pressure has a negative correlation with the company's capability in performing integrated reporting. It means if the stakeholder's pressure increases, the companies tend to not disclose financial and non-financial information on integrated reporting (the companies has a lower ability to perform integrated reporting).

Based on the result of hypothesis testing, it can be seen that the first hypothesis was rejected, which means that the level of company's profitability did not affect the company's capability to perform integrated reporting. There is no evidence to support that the level of corporate profitability affects the company's ability to perform integrated reporting. It seems that the profitability is not the main factor that is able to encourage companies to undertake integrated reporting, even though the research was conducted on the companies listed on the SRI-KEHATI stock index and the companies participating in the ISRA competition.

The profitability level is a measure to examine the management performance in conducting business activities. High profitability is the outcome of using the company's resources efficiently and effectively. Company's management with high profitability is not using profitability level as the main guideline to measure the level of non-financial information disclosure (in other words do not encourage companies to undertake integrated reporting). This result also support a research result from Chen et al. (2018) which found that corporate social responsibility reporting did not have strong connection with the company's profitability. One of the assumptions that may explain why the rate of profitability does not encourage companies to undertake integrated reporting is that the internal mechanism inside the company listed on the SRI-KEHATI stock index and companies participating in the ISRA competition has become a major factor. 
Huang (2010) stated that corporate governance is the major factor in corporate social responsibility and corporate governance mechanism can help the company's management disclose their non-financial information. The internal mechanism in this context is good corporate governance and a high commitment from the company's management (board of directors). The corporate governance of companies listed on SRI-KEHATI stock index and companies participating in the ISRA competition have demonstrated a strong commitment to implementing the concept of sustainability on the company's business activities. This reason makes the level of corporate profitability is not the main factor driving the company's capability in performing integrated reporting. The result of this research has expressed the opinion that corporate governance is one of the main factors that encourage companies to undertake integrated reporting. Another factor that may support company's management to disclose their integrated report is the commitment of the board of directors to implement the concept of sustainability in the company's business activities. In the speech of directors on corporate sustainability report samples, it can be seen that the company's management has explained the company's commitment in the context of sustainability. The management commitment will be revealed in the company's internal policies and the policies will encourage companies to improve their role in the context of sustainability.

Hypothesis testing result showed that the second hypothesis is accepted, then it can be concluded that the company's size has a positive effect and significant on the company's ability to perform integrated reporting. The result of this research has supported the opinion or theory which states that the company's size is one of the main factors that encourage the company's management to expand the disclosure of financial information and non-financial information. The results of this study reinforce the view that companies with a large size get a strong monitoring from the investors and the company's stakeholders. Galani et al. (2011) and Zadeh \& Eskandari (2012) stated that based on the point of view of legitimacy theory and stakeholder theory, a company with a large size requires a defense strategy to reduce the impact from strong monitoring activity. The company's size can be one factor that strengthens the company's management motivation to build their sustainability reporting and integrated reporting concept, particularly to disclose environmental information (Galani et al., 2011). The result of this research also supports the research results conducted by Frias-Aceituno et al. (2013) who also found that the company's size is one of the factors that support the integrated reporting process. Another explanation describes that the company with a large size has high ability and sufficient resources to create their integrated reporting process. Integrated reporting process requires the coordination from all parts of the company and reporting costs are very high.

Hypothesis testing result showed that the third hypothesis was rejected, which means that the managerial ownership level did not affect the company's ability to perform integrated reporting. The result of this research supports previous studies which suggest that the level of managerial ownership does not significantly influence the company's ability to perform integrated reporting. The result of this study has a different result with Frias-Aceituno et al. (2013) and Stubbs \& Higgins (2014) which stated that the existence of the board of directors can help the integrated reporting process or in other words, the corporate governance mechanism can support the development of integrated reporting.

The author believes that this result is different from the research result from Frias-Aceituno et al. (2013) due to the difference of the corporate governance characteristics. Based on their research, Frias-Aceituno et al. (2013) concluded that the 
integrated reporting process will develop if the model of corporate governance that is used in the company's corporate governance model is the Anglo-Saxon, Germanic, and Latin. The result of this study does not support the research result carried out by Steyn (2014). The result from Steyn (2014) found that the company's directors in South Africa strongly supports the integrated reporting process. The integrated reporting process needs the rules or policies that support it and in South Africa there have been a rules about integrated reporting for companies listed on the capital market. The result of this study found that for the Indonesian case, the managerial ownership level does not have a significant effect on the company's capability in performing integrated reporting. This may be due to the statistically average number of managerial ownership level in Indonesia companies is relatively small, then there has been no alignment of interests between owners and managers. The existence of this relatively small managerial ownership level caused the manager has not been able to maximize value through disclose financial information and non-financial information on company's report.

The result of the hypothesis testing explains that the fourth hypothesis is rejected, which means it can be concluded that the level of institutional ownership has no effect on the company's capability to perform integrated reporting. The result of this study has not been able to support the idea from Abeysekera (2013) which states that the current paradigm shift investors interest to support the non-financial disclosure. The logical explanation that can be put forward why institutional investors have not been a major factor to support the company conducts integrated reporting because the institutional investor in Indonesian companies has not been focused on a comprehensive disclosure, especially non-financial information disclosure. The results of this study are different from the results obtained by Frias-Aceituno et al. (2013) which explained that the corporate governance mechanism is a positive factor that encourages integrated reporting process.

The hypothesis testing result showed that the stakeholder's pressure had a negative effect on the company's capability in performing integrated reporting. This result shows that when the company's stakeholder pressure increases (in other words, information request is increased to the company's management), company's management tends to reduce the information disclosure level. The result of this study has not been able to support the opinion from Zadeh and Eskandari (2012), which explained that the company's management will improve information disclosure to company's stakeholder to reduce the information asymmetry problem. Logical explanation that can be put forward to explain this result is this study using companies incorporated in the SRI-KEHATI stock index and companies that participate in ISRA competition which incidentally is a company that has been doing the financial and non-financial information reporting comprehensively and have a high commitment to execute the sustainability concept in the company's business activities. Companies in this circumstance will be mandatory to disclose their economic performance, social performance, and environmental performance with excellent quality.

Setia et al. (2015) found that companies in South Africa disclose their integrated report because their business circumstances and the rules from government. McNally et al. (2017) stated that stakeholder's pressure is one challenge to create a perfect integrated reporting behavior in our business system. The impact of this process is the monitoring activity conducted by the stakeholder's group will be reduced due to the company's management has been disclosed all information comprehensively. The main result is a request for information from stakeholders to the company's management to be relatively small because the company's management has revealed the financial 
information and non-financial information comprehensively. In other words, companies that are members of the SRI-KEHATI stock index and have been known to carry out the sustainability concept in their business activities will have a small pressure from their stakeholders because all stakeholder groups have gained sufficient and complete information from the company's management. Small pressure from stakeholder's group has made the company in SRI-KEHATI stock index and companies that participate in ISRA competition improve their information quality. The major motivation to disclose financial information and non-financial information in this context is based on the internal factor, such as company's vision and mission to build sustainability concept in their business activities, and not based on the stakeholder's pressure.

Based on previous literature, there are two main factors to support the implementation of integrated reporting process in Indonesia. The first factor is internal factor, such as internal mechanism (corporate governance mechanism and management's commitment). Kolk (2008) found that corporate governance is the main factor to support the company's sustainability and company's accountability. Utama (2011) had a interesting statement that we need to evaluate our infrastructures in the context of corporate responsibility reporting in Indonesia and internal mechanism is the key answer to start the implementation of corporate responsibility reporting for Indonesian companies. Unfortunately, this research did not support the statement from Kolk (2008) and Utama (2011). In the future, the government or the policymaker should create a long-term plan how to increase the company's internal mechanism and the management's commitment in the context of sustainability reporting or integrated reporting. The second factor is external factor, such as the rules from the government. McNally et al. (2017) found that the policymaker should build a clear rules and comprehensive framework for integrated reporting prcess which relevant with the company's business models. This statement is support the result from FernandezFeijoo et al. (2014) which stated that the pressure from some groups of stakeholders will increase the company's transparency, particularly in company's sustainability reporting.

\section{CONCLUSION}

This study found that the company's size had a positive effect and significant on the company's ability to perform integrated reporting and stakeholder's pressure had a negative effect and significant on the company's capability in performing integrated reporting. The results of this study concluded that firms with a large size (reflected by total assets) received a strong monitoring process from the company's stakeholders. The results of this study also concluded that the level of managerial ownership did not affect the integrated reporting process. The results of this research also found that companies belonging to the SRI-KEHATI stock index and companies participating in the ISRA competition have a small stakeholder's pressure than companies that are not incorporated in the SRI-KEHATI stock index and companies that do not participate in the ISRA competition.

The limitation of this study is the company's population which used in the research process, this research only used listed companies in SRI-KEHATI stock index and companies in ISRA competition. The impact of this limitation is the result of this research has not been able to reflect the comprehensive discussion related to company's capability in Indonesia to conduct integrated reporting process. In the future research, this research will try to use the methodology from the study conducted by Frias-Aceituno et al. (2013) which used a sample of companies in 15 countries. 
Another limitation of this research is the absence of the perfect method for measuring the stakeholder's pressure variable within the context of this study. The stakeholder's pressure in this study only seen from the level of government ownership and majority ownership. This measurement technique can be improved in the future research with a more precise measurement method. This study also has a limitation on the terms of the social and environmental information measurement. Measurement of social and environmental information in this research is only done by looking at the company report (company's sustainability report and company's integrated report). This method will create a wrong measurement because not all social and environmental activities of the companies included in the company's report. Subsequent research can develop a new method to measure the social and environmental information which appropriate with the context of this research.

This research is expected to has an implication for the development of integrated reporting in Indonesia. The company's management that has expressed financial information and non-financial information has shown a high commitment to implement the sustainability concept in the company's operating activities. The results of this study are expected to support the development of policies to promote integrated reporting in the future. Integrated reporting has an important position for a business ecosystem in Indonesia. The integrated reporting process will increase the information flow to the company's stakeholder and this process will improve the information quality. The major impact is this process will increase the quality of decision-making process by the company's stakeholders. This impact will create a new concept that the quality of information which disclosed by company's management has a linier connection with the quality of stakeholder's decision.

This study implies that basically, the company's management should disclose all types of information to the company's stakeholder. The company's management should realize that accountability in the information delivery is important because the problem of information asymmetry between the company's management and company's stakeholders (Rusdianto, 2013). In addition, Utama (2011) argues that the information asymmetry can be reduced if the company's management creates a disclosure about its social and environmental activities to their stakeholders. The problem of information asymmetry will have a negative impact on company's stakeholder decision making process. Disclosing comprehensive information through integrated report concept can help eliminate the adverse effects of asymmetric information. Another implication of this study showed that the quality of information provided to each stakeholder group should have the same quality. The social and environmental information to be delivered from the company's management to the relevant stakeholders (in outside of the company) should be equal in quality and quantity with the information presented to the company's shareholders. This process will create the fairness and equality in the disclosure level by the company's management. It should be understood that the interests of each stakeholder groups are different and the company's management is required to disclose the information in a comprehensive manner.

Another implication of this study indicates that the variables that represent the concept of corporate governance mechanisms (the level of managerial ownership and the level of institutional ownership) do not have a strong influence on the company's capability in performing integrated reporting. The results showed that for samples companies in Indonesia, the variable of corporate governance mechanisms are not recommended for represent as independent variables when the dependent variable is the disclosure level of social and environmental information and the company's ability 
to perform integrated reporting. This study supports other research that found the company's internal mechanisms did not have enough effect for Indonesian companies in the context about social and environmental reporting or integrated reporting. The company's internal mechanism does not yet support non-financial disclosure, and this fact should be a consideration of policymakers. To improve the company's internal mechanisms in support of integrated reporting will require comprehensive policies to manage this mechanism. It must be realized that basically the commitment and motivation to build integrated reporting process should be based on the company's internal mechanism and the company's internal sources.

\section{REFERENCES}

Abeysekera, I. (2013). A template for integrated reporting. Journal of Intellectual Capital, 14(2), 227-245. https://doi.org/10.1108/14691931311323869

Ali, W., \& Rizwan, M. (2013). Factors Influencing Corporate Social and Environmental Disclosure (CSED) Practices in the Developing Countries: An Institutional Theoretical Perspective. International Journal of Asian Social Science, 3(3), 590-609. Retrieved from https://ideas.repec.org/a/asi/ijoass/2013p590-609.html

Amran, A., \& Keat Ooi, S. (2014). Sustainability reporting: meeting stakeholder demands. Strategic Direction, 30(7), 38-41. https://doi.org/10.1108/SD-03-20140035

Bidaki, S., \& Hejazi, R. (2014). Effects of profitability on the Intellectual Capital Disclosure in listed Companies in Tehran Stock Exchange. Journal of Education and Applied Sciences, 1(5), 248-255.

Chen, Y.-C., Hung, M., \& Wang, Y. (2018). The effect of mandatory CSR disclosure on firm profitability and social externalities: Evidence from China. Journal of Accounting and Economics, 65(1), 169-190. https://doi.org/10.1016/J.JACCECO.2017.11.009

David, P., \& Kochhar, R. (1996). Barriers to effective corporate governance by institutional investors: Implications for theory and practice. European Management Journal, 14(5), 457-466. https:// doi.org/10.1016/0263-2373(96)00039-4

de Villiers, C., Rinaldi, L., \& Unerman, J. (2014). Integrated Reporting: Insights, gaps and an agenda for future research. Accounting, Auditing $\mathcal{E}$ Accountability Journal, 27(7), 1042-1067. https:/ / doi.org/10.1108/AAAJ-06-2014-1736

Dumay, J., Bernardi, C., Guthrie, J., \& Demartini, P. (2016). Integrated reporting: A structured literature review. Accounting Forum, 40(3), 166-185.

Fernandez-Feijoo, B., Romero, S., \& Ruiz, S. (2014). Effect of Stakeholders' Pressure on Transparency of Sustainability Reports within the GRI Framework. Journal of Business Ethics. Springer. https://doi.org/10.2307/42921416

Flower, J. (2015). The International Integrated Reporting Council: A story of failure. Critical Perspectives on Accounting, 27, 1-17. https://doi.org/10.1016/J.CPA.2014.07.002

Frias-Aceituno, J. V., Rodriguez-Ariza, L., \& Garcia-Sanchez, I. . (2013). The Role of the Board in the Dissemination of Integrated Corporate Social Reporting. Corporate Social Responsibility and Environmental Management, 20(4), 219-233. https://doi.org/10.1002/csr.1294

Galani, D., Gravas, E., \& Stavropoulos, A. (2011). The Relation between Firm Size and Environmental Disclosure. In International Conference on Applied Economics ICOAE (pp. 179-186).

Huang, C.-J. (2010). Corporate governance, corporate social responsibility and corporate performance. Journal of Management $\mathcal{E}$ Organization, 16(05), 641-655. 
https://doi.org/10.1017/S1833367200001784

Jo, H., \& Harjoto, M. A. (2011). Corporate Governance and Firm Value: The Impact of Corporate Social Responsibility. Journal of Business Ethics, 103(3), 351-383. https://doi.org/10.1007/s10551-011-0869-y

Kolk, A. (2008). Sustainability, accountability and corporate governance: exploring multinationals' reporting practices. Business Strategy and the Environment, 17(1), 115. https:// doi.org/10.1002/bse.511

KPMG. (2011). KPMG International Survey of Corporate Responsibility Reporting 2011. KPMG International.

McNally, M.-A., Cerbone, D., \& Maroun, W. (2017). Exploring the challenges of preparing an integrated report. Meditari Accountancy Research, 25(4), 481-504. https://doi.org/10.1108/MEDAR-10-2016-0085

Rouf, D. M. (2011). The Financial Performance (Profitability) and Corporate Governance Disclosure in the Annual Reports of Listed Companies of Bangladesh. Journal of Economics and Business Research, XVII(2), 103-117. Retrieved from https://papers.ssrn.com/sol3/papers.cfm?abstract_id=2570686

Rusdianto, U. (2013). CSR Communications A Framework for PR Practitioners. Yogyakarta: Graha Ilmu.

Sawarjuwono, T. (2012). Aspek Perilaku Manusia dalam Dunia Akuntansi (Akuntansi Keperilakuan). Surabaya: Airlangga University Press.

Setia, N., Abhayawansa, S., Joshi, M., \& Huynh, A. V. (2015). Integrated reporting in South Africa: some initial evidence. Sustainability Accounting, Management and Policy Journal, 6(3), 397-424. https:// doi.org/10.1108/SAMPJ-03-2014-0018

Solomon, J., \& Maroun, W. (2012). Integrated Reporting: The Influence of King III on Social, Ethical and Environmental Reporting. London: The Association of Chartered Certified Accountants.

Steyn, M. (2014). Organisational benefits and implementation challenges of mandatory integrated reporting. Sustainability Accounting, Management and Policy Journal, 5(4), 476-503. https:// doi.org/10.1108/SAMPJ-11-2013-0052

Stubbs, W., \& Higgins, C. (2014). Integrated Reporting and internal mechanisms of change. Accounting, Auditing $\mathcal{E}$ Accountability Journal, 27(7), 1068-1089. https:/ / doi.org/10.1108/ AAAJ-03-2013-1279

Utama, S. (2011). An evaluation of support infrastructures for corporate responsibility reporting in Indonesia. Asian Business $\mathcal{E}$ Management, 10(3), 405-424. https://doi.org/10.1057/abm.2011.10

van Beurden, P., \& Gössling, T. (2008). The Worth of Values - A Literature Review on the Relation Between Corporate Social and Financial Performance. Journal of Business Ethics, 82(2), 407-424. https://doi.org/10.1007/s10551-008-9894-x

Zadeh, F. O., \& Eskandari, A. (2012). Firm Size As Company's Characteristic and Level of Risk Disclosure: Review on Theories and Literatures. International Journal of Business and Social Science, 3(17). 